\title{
DNA-Dependent RNA Polymerases of the three Orders of Methanogens
}

\author{
Michael Thomm, Jerzy Madon and Karl O. Stetter \\ Lehrstuhl für Mikrobiologie der Universität Regensburg
}

(Received 25 March 1985)

\author{
Summary: The DNA-dependent RNA poly- \\ merases of members of the three orders of \\ methanogens were purified and their enzymatic \\ properties described. The enzymes consist of \\ 7-8 polypeptides. Although these differed in \\ molecular mass, the four heaviest components \\ could be allied to components of the enzyme \\ of Methanobacterium thermoautotrophicum, \\ W by cross-reaction with antibodies directed \\ against the denatured polypeptides of this \\ enzyme.
}

The antisera against native RNA polymerases isolated from representatives of the different orders, on the other hand, gave rise to serological cross-reaction between different genera but not between different families and orders. These antisera are thus useful for taxonomic purposes. The RNA polymerase of the extreme thermophile Methanothermus fervidus shows a rather low thermostability. No factors having a stabilizing influence on the enzyme could be detected.

\section{DNA-abhängige RNA-Polymerasen innerhalb der drei Ordnungen methanogener Bakterien}

Zusammenfassung: Die DNA-abhängigen RNAPolymerasen aus Vertretern der drei Ordnungen methanogener Bakterien wurden isoliert und deren enzymatische Eigenschaften untersucht. Diese Enzyme bestehen aus 7-8 Polypeptidketten mit unterschiedlichen Molekularmassen. Anhand von Antiseren gegen die denaturierten Untereinheiten der RNA Polymerase von Methanobacterium thermoautotrophicum, $\mathrm{W}$, konnten die 4 schwersten Untereinheiten aller Enzyme serologisch zugeordnet werden.

Antiseren gegen die nativen RNA-Polymerasen aus verschiedenen methanogenen Bakterien reagierten dagegen nur innerhalb verschiedener Gattungen, nicht aber mit RNA-Polymerasen aus Vertretern anderer Familien oder Ordnungen kreuz. Deshalb können diese Antiseren auch für taxonomische $Z$ wecke verwendet werden.

Die RNA-Polymerase aus dem extrem thermophilen Bakterium Methanothermus fervidus ist in vitro nur $23^{\circ} \mathrm{C}$ unterhalb der optimalen Wachstumstemperatur dieses Stammes stabil. Es konnten keine Faktoren nachgewiesen werden, die einen stabilisierenden Effekt auf das Enzym ausüben.

Key words: RNA polymerase, methanogens, transcription, taxonomy, thermophily.

On the basis of comparative analysis of the T1 ribonuclease oligonucleotides of $16 \mathrm{~S}$ rRNAs, the methanogenic bacteria can be divided into three phylogenetic orders: the Methanobacteri-

\section{Enzyme:}

DNA-directed RNA polymerase, nucleoside-triphosphate:DNA deoxynucleotidyltransferase (DNA-directed)

(EC 2.7.7.6). 
ales, the Methanococcales and the Methanomicrobiales. Representatives of these orders differ with respect to physiology, morphology and the temperatures at which growth takes place ${ }^{[1,2]}$. Within the methanogens only the purifications of the RNA polymerase of one representative of each of the Methanobacteriales $^{[3]}$ and the Methanococcales ${ }^{[4]}$ have been described hitherto. In order to establish the structure of RNA polymerase also within the Methanomicrobiales we isolated the enzyme of Methanosarcina barkeri and of strain PL12/M, an isolate whose relationship to other members of the Methanomicrobiales was unclear. Antisera raised against these enzymes and the RNA polymerases of representatives of the two other orders of methanogens were used for the classification of PL12/M.

Analyses of the RNA polymerases of methanogens employing antisera directed against the single subunits of $\mathrm{Mb}$. thermoautotrophicum, W yielded evidence that the four heaviest components of the RNA polymerases of methanogens are homologous ${ }^{[5,6]}$, as suggested by the similarity of the polypeptide patterns concerned. The enzyme of $M b$. thermoautotrophicum, Marburg, isolated by immunoprecipitation with a heterologous antiserum ${ }^{[7]}$, however, showed a quite different polypeptide pattern compared to that of the enzyme from $M b$. thermoautotrophicum, $\mathrm{W}$, thus indicating a possible heterogenous structural organization of the RNA polymerases within the Methanobacteriales. This enzyme and the enzyme of Mth. fervidus, a further member of the Methanobacteriales only distantly related to $M b$. thermoautotrophicum (Stackebrandt and Woese, pers. comm.) have therefore been isolated in this study and the immunological relationship of RNA polymerases within the Methanobacteriales investigated using antisera against the native enzyme and against single components of the RNA polymerase of $M b$. thermoautotrophicum, $\mathrm{W}$.

The RNA polymerase of Mth. fervidus, representing the most thermophilic methanogen hitherto known ${ }^{[8]}$, was selected to implement a comparison of the properties of this enzyme with those of the corresponding enzymes of extreme thermophiles of the sulfur-dependent branch of the archaebacteria.

\section{Materials and Methods}

\section{Bacterial strains and large-scale culturing}

The methanogenic bacteria were grown anaerobically as described by Balch and Wolfe ${ }^{[9]}$. Methanosarcina strain G 1, DSM 3338 and the isolate PL12/M were grown at $37^{\circ} \mathrm{C}$ in $20-l$ bottles in medium 1 of Balch et al. ${ }^{[1]}$ with $0.5 \%$ methanol (v/v). Mb. thermoautotrophicum strain W and strain Marburg were cultivated in 10-l fermentors (Braun-Melsungen, D-3508 Melsungen) in medium 2 of Balch et al. ${ }^{[1]}$ at $60{ }^{\circ} \mathrm{C}$; Mth. fervidus was grown in a $300-l$ enamel-coated fermentor at $85{ }^{\circ} \mathrm{C}$ in MM medium ${ }^{[8]}$. Mass culturing of Mc. thermolithotrophicus was carried out as described previously ${ }^{[4]}$.

\section{Purification of the RNA polymerases}

The isolation of all enzymes was carried out at $20{ }^{\circ} \mathrm{C}$ in an anaerobic chamber (Coy Manufacturing Company, Ann Arbor, USA) under the exclusion of oxygen as described previously $[3]$.

\section{RNA polymerase of Methanosarcina}

Hydrophobic interaction chromatography on phenylSepharose as described for the purification of the RNA polymerase of $M c$. thermolithotrophicus ${ }^{[4]}$ comprised the initial step of the purification. The further purification of the enzyme was effected by DEAE cellulose-, DNA agarose- and heparin cellulose-chromatography $[4,10]$.

\section{RNA polymerase of $P L 12 / M$}

The endogenous nucleic acids of this strain were separated from a crude extract adjusted to $2 \mathrm{M} \mathrm{KCl}$ by precipitation with PEG 6000 as described by Humphries et al. [11]. The RNA polymerase was then purified from the PEG supernatant according to the procedure used for the enzyme of Methanosarcina.

\section{RNA polymerase of Methanothermus fervidus}

The first step of purification employed dextran/PEGphase partitioning as described for the RNA polymerase of Halobacterium halobium ${ }^{[12]}$. Final purification of the enzyme was achieved by heparin cellulose- and phosphocellulose-chromatography and sucrose-glycerol gradient centrifugation ${ }^{[10,13]}$.

RNA polymerase of $\mathrm{Mb}$. thermoautotrophicum, Marburg The first step of purification was the same as that used for the enzyme of Mth. fervidus. Further purification was effected by a procedure developed for the isolation of the RNA polymerase of $H$. halobium ${ }^{\text {[12], involving }}$ DEAE cellulose- and heparin cellulose-chromatography.

RNA polymerase of $\mathrm{Mb}$. thermoautotrophicum, $W$ This enzyme was purified as described by Stetter et al. ${ }^{[3]}$. PEG-precipitation as an initial purification step ${ }^{[11]}$ proved, however, to be the most efficient procedure and was therefore substituted for polyethylenimine precipitation.

RNA polymerase of Mc. thermolithotrophicus This enzyme was purified as described previously ${ }^{[4]}$.

Preparation of crude extracts of Mth. fervidus

$2 \mathrm{~g}$ cells were suspended in $2 \mathrm{ml}$ buffer [ $50 \mathrm{mM}$ Tris $/ \mathrm{HCl}$, $\mathrm{pH} 7.5,50 \mathrm{mM} \mathrm{MgCl}_{2}, 50 \mathrm{~mm}$ dithiothreitol, $40 \%$ glycerol (v/v)] and disrupted at $140 \mathrm{MPa}$ in a French pressure cell. 


\section{Preparation of antibodies}

Rabbits were immunized with a total of $180 \mu \mathrm{g}$ of native RNA polymerase or single poly peptides eluted from SDS-poly acrylamide gels as described ${ }^{[5]}$, using the micromethod of Stetter ${ }^{[14]}$

\section{Ouchterlony assay}

The immunodiffusion assay ${ }^{[15]}$ was performed in $1 \%$ $(\mathrm{w} / \mathrm{v})$ agarose gels containing $0.05 \mathrm{M}$ Tris $/ \mathrm{HCl}, \mathrm{pH} 7$, $50 \mathrm{mM} \mathrm{KCl}, 10 \mathrm{mM} \mathrm{MgCl}_{2}$, and $10 \%$ glycerol (v/v).

Determination of homology of RNA polymerase components

Transfer of RNA polymerase components to nitrocellulose filters subsequent to SDS polyacrylamide gel electrophoresis was performed as described by Schnabel et al. ${ }^{[5]}$. Antibodies bound to the RNA polymerases were detected by peroxidase-coupled anti-rabbit IgG antibodies from goat (Sigma, D-8028 Taufkirchen) according to the method of Towbin et al. ${ }^{[16]}$.

\section{RNA polymerase assay conditions}

RNA polymerase fractions were incubated in standard assays ${ }^{[3,4]}$ using [ $\left.{ }^{32} \mathrm{P}\right] \mathrm{UTP}$ ( $M$ th. fervidus and $M b$. thermoautotrophicum, Marburg) or $\left[{ }^{14} \mathrm{C}\right] \mathrm{ATP}$ (all other enzymes) as labeled ribonucleosidetriphosphate. The incubation mixture contained $12 \mathrm{mM} \mathrm{MgCl}_{2}$ (in the case of Methanosarcina), $20 \mathrm{mM} \mathrm{MgCl} 2$ (PL12/M) or $20 \mathrm{mM}$ $\mathrm{MgCl}_{2}$ and $150 \mathrm{mM} \mathrm{KCl}$ (Mth. fervidus and $M b$. thermoautotrophicum, Marburg). The incubation temperature was $55^{\circ} \mathrm{C}$ in each case.

For the determination of the RNA polymerase activity in crude extracts of Mth. fervidus, assay mixtures were additionally supplemented with actinomycin D at a final concentration of $100 \mu \mathrm{g} / \mathrm{ml}$ to eliminate activity resulting from transcription of endogenous DNA.

The radioactivity of the material precipitated by $5 \%$ $(\mathrm{w} / \mathrm{v})$ trichloroacetic acid was measured in a scintillation counter (Berthold, D-7547 Wildbad).

\section{Polyacrylamide gel electrophoresis}

Polyacrylamide slab gels were prepared according to Laemmli ${ }^{[17]}$, employing 5-25\% exponential gradient gels ${ }^{[18]}$.

\section{Protein determination}

Protein concentrations were determined by the micromethod of Heil and Zillig[19].

\section{Results}

\section{Specific precautions for the isolation of the} $R N A$ polymerases

Although polyethylenimine precipitation is a very useful initial step in the purification of RNA polymerases from eubacteria ${ }^{[20,21]}$ and sulfurdependent archaebacteria ${ }^{[10]}$, the RNA polymerases from most methanogens were inactivated by this procedure. Only the enzyme of $M b$. thermoautotrophicum, strain $\mathrm{W}^{[3]}$, could be isolated with the aid of this technique.
The phenyl-Sepharose method, introduced for the purification of the RNA polymerase of Mc. thermolithotrophicus ${ }^{[4]}$, proved also to be useful for the separation of the RNA polymerase of Methanosarcina from endogenous DNA. In the case of the isolate PL12/M, however, all attempts to elute the RNA polymerase from phenyl-Sepharose columns failed. It was therefore separated from the endogenous template by polyethyleneglycol precipitation ${ }^{[11]}$.

The RNA polymerases of $M t h$. fervidus and $M b$. thermoautotrophicum, strain Marburg, were purified by the use of phase partitioning ${ }^{[22]}$ as initial step, a technique which has already been employed with the RNA polymerases of halophilic archaebacteria ${ }^{[12,23]}$.

The further purification of the RNA polymerases of Methanosarcina, PL12/M, Mb. thermoautotrophicum, strain Marburg, and Mth. fervidus was achieved by using modifications of the chromatographic procedures developed for the isolation of the RNA polymerases of Mc. thermolithotrophicus ${ }^{[4]}$ and halophilic archaebacteria $^{[12]}$.

The enzyme of Methanosarcina could not be eluted from DNA cellulose-columns even in the presence of $4 \mathrm{M} \mathrm{NaCl}$. This phenomenon was not due to interaction with the DNA, as the enzyme also bound irreversibly to the cellulose alone (data not shown). DNA agarose-chromatography was therefore employed instead.

The enzymes of the two members of the $M e$ thanomicrobiales were inactivated upon sucrosegradient centrifugation. Analysis of gradient fractions by SDS polyacrylamide gel electrophoresis revealed the presence of RNA polymerase components even in uppermost fractions of the gradient, a region usually containing only low molecular mass proteins (data not shown). The RNA polymerases of the Methanomicrobiales therefore are dissociated into polypeptide components during gradient-centrifugation. Final purification of these enzymes was achieved by heparin cellulose-chromatography.

The RNA polymerase of $M t h$. fervidus - as a single exception - did not bind to DEAE-cellulose. This step was therefore replaced by phosphocellulose-chromatography.

\section{Polypeptide composition}

Only those polypeptides which copurified with each other and the enzyme activity in at least two steps of the purification procedure were considered to be true enzyme components, as shown for example in Fig. 1 for the RNA polymerase of Methanosarcina. Further evidence for 
Table 1. Molecular masses of the components of DNA-dependent RNA polymerases from different methanogens.

The molecular masses of the components were determined by comparing their electrophoretic mobilities in SDS polyacrylamide gel electrophoresis with those of standard proteins. Myosin (200 000), $\beta$-galactosidase (116250), phosphorylase $b$ ( 92500$)$, bovine serum albumin (66200), ovalbumin (45 000), carbonate dehydratase (28 000), trypsin inhibitor (21 500), cytochrome $c(12500)$ and aprotinin (6500) were used as standards. The molecular masses of the native enzymes were estimated from the molecular masses and stoichiometry of enzyme components. Molar ratios of components were determined by densiometric scanning of the Coomassiestained polypeptides after SDS polyacrylamide gel electrophoresis. Molecular masses are given in kDa.

\begin{tabular}{|c|c|c|c|c|c|c|}
\hline $\begin{array}{l}\text { Component } \\
\text { (designation) }\end{array}$ & $\begin{array}{l}\text { Mb. thermo- } \\
\text { autotrophi- } \\
\text { cum, } \mathrm{W}\end{array}$ & $\begin{array}{l}\text { Mb. thermo- } \\
\text { autotrophi- } \\
\text { cum, Marburg }\end{array}$ & Mth. fervidus & $\begin{array}{l}\text { Mc. thermo- } \\
\text { lithotrophicus }\end{array}$ & $\begin{array}{l}\text { Methano- } \\
\text { sarcina spec. }\end{array}$ & $\begin{array}{l}\text { PL12/M } \\
\text { (“Ml. vulcani") }\end{array}$ \\
\hline $\begin{array}{l}1(\mathrm{~A}) \\
2\left(\mathrm{~B}^{\prime}\right) \\
3\left(\mathrm{~B}^{\prime \prime}\right) \\
4(\mathrm{C}) \\
5(\mathrm{D}) \\
6 \\
7 \\
8\end{array}$ & $\begin{array}{c}97 \\
78 \\
65 \\
57 \\
35 \\
24 \\
10 \\
6.5\end{array}$ & $\begin{array}{c}123 \\
82 \\
59 \\
54 \\
33 \\
22 \\
10 \\
6.5\end{array}$ & $\begin{array}{l}97 \\
77 \\
63 \\
44 \\
35 \\
31 \\
10 \\
6.5\end{array}$ & $\begin{array}{c}100 \\
79 \\
60 \\
55 \\
26 \\
22 \\
- \\
6.5\end{array}$ & $\begin{array}{l}98 \\
76 \\
71 \\
48 \\
28 \\
- \\
7 \\
6.5\end{array}$ & $\begin{array}{l}99 \\
76 \\
78 \\
47 \\
34 \\
30 \\
- \\
6.5\end{array}$ \\
\hline Native enzyme & 405 & 421 & 395 & 390 & 334 & 390 \\
\hline
\end{tabular}

a)
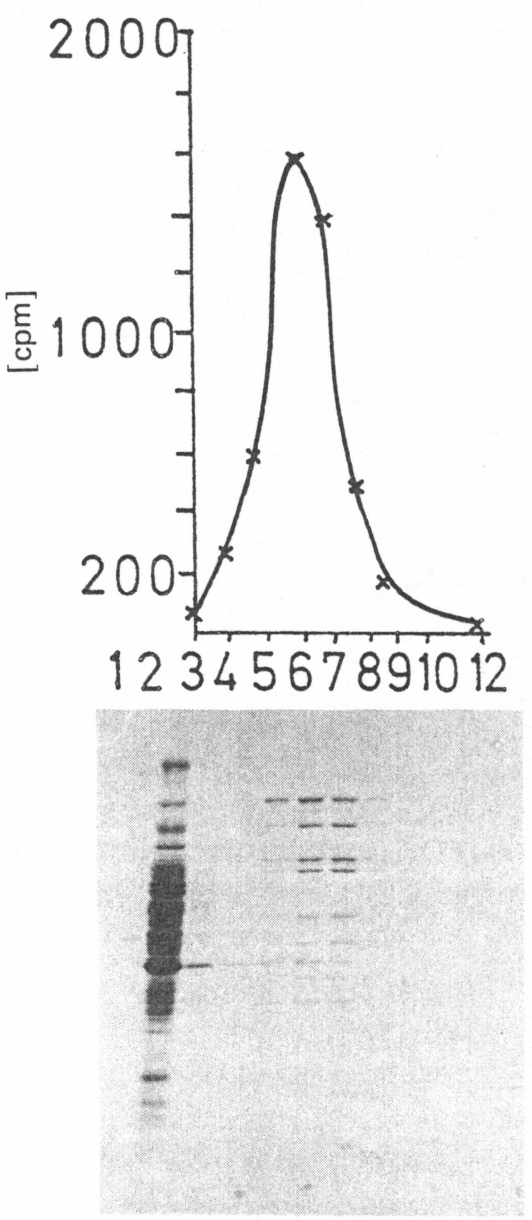

b)

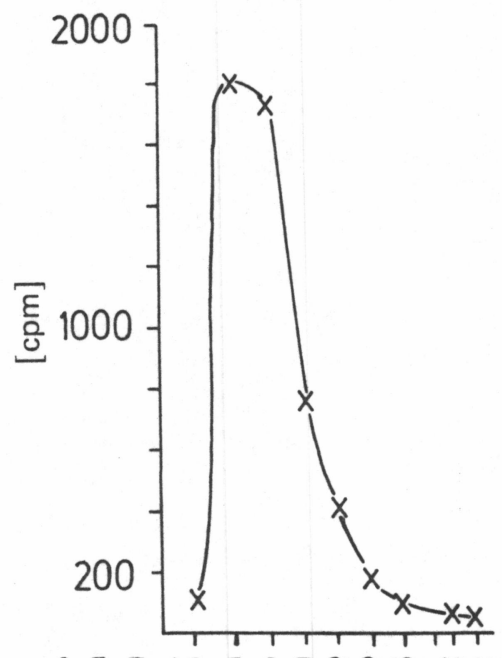

IIIIII356789101214 IV

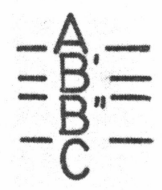

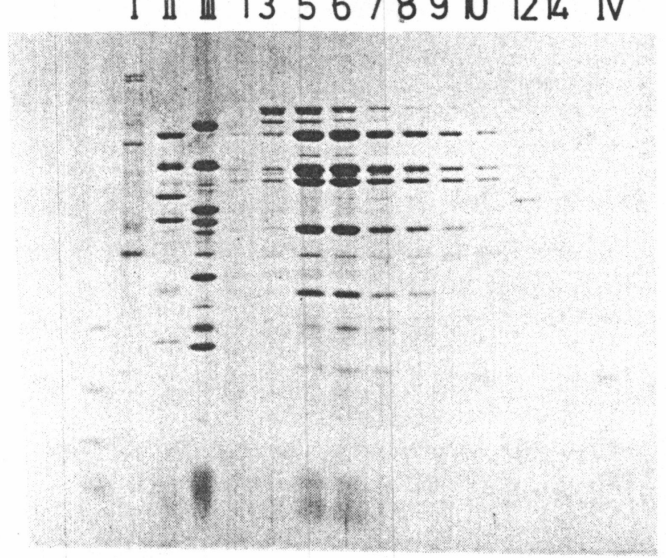

Fig. 1. Purification of the DNA-dependent RNA polymerase of Methanosarcina.

Lower part of the figures: SDS polyacrylamide gels of polypeptides eluted from DNA agarose (a) and heparin cellulose (b). a) Lane 1, RNA polymerase of $E$. coli; lane 2, flow through-fraction; lanes 3-11 fractions eluted from the DNA agarose. b) Lanes 3-14, fractions eluted from heparin cellulose; lanes I-IV reference substances: RNA polymerase of $E$. coli (I), $M b$. thermoautotrophicum, W (II) and Mc. thermolithotrophicus (III); trypsin inhibitor (21500 $\mathrm{Da}, \mathrm{IV})$ and cytochrome $c(12500 \mathrm{Da}, \mathrm{IV})$. The positions of the four heaviest polypeptides of the RNA polymerase are indicated between the polyacrylamide gels. Upper part of the figures: corresponding activity curves. 
Table 2. Enzymatic properties of DNA-dependent RNA polymerases from methanogenic bacteria. n.d. $=$ not determined.

\begin{tabular}{|c|c|c|c|c|c|}
\hline & \multicolumn{2}{|c|}{ Optimum concentr. } & \multirow{2}{*}{$\begin{array}{l}\mathrm{pH} \\
\text { optimum }\end{array}$} & \multirow{2}{*}{$\begin{array}{l}\text { T optimum of } \\
\text { transcription } \\
{\left[{ }^{\circ} \mathrm{C}\right]}\end{array}$} & \multirow{2}{*}{$\begin{array}{l}\text { Optimal growth } \\
\text { temperature of the } \\
\text { organism }\left[{ }^{\circ} \mathrm{C}\right]\end{array}$} \\
\hline & $\begin{array}{l}\mathrm{KCl} \\
{[\mathrm{mM}]}\end{array}$ & $\begin{array}{l}\mathrm{MgCl}_{2} \\
{[\mathrm{mM}]}\end{array}$ & & & \\
\hline Mb. thermoautotrophicum, $\mathrm{W}$ & 200 & $10-30$ & 8.0 & 60 & $65-70^{[25]}$ \\
\hline $\begin{array}{l}\text { Mb. thermoautotrophicum, } \\
\text { Marburg }\end{array}$ & 175 & 7.5 & 8.5 & 57 & $60^{[7]}$ \\
\hline Mth. fervidus & 200 & 25 & n.d. & 65 & $83^{[8]}$ \\
\hline Methanosarcina spec. & 0 & 20 & 7.7 & 50 & $37 *$ \\
\hline $\mathrm{PL12} / \mathrm{M}$ & 50 & 20 & n.d. & $35-50$ & $37 * *$ \\
\hline Mc. thermolithotrophicus & 100 & 20 & 8.7 & $55-60$ & $65^{[26]}$ \\
\hline
\end{tabular}

* Hippe, H., pers. communication.

** Stetter, Thomm and König, unpublished.

the significance of these polypeptides as enzyme constituents was provided by the immunological homology of the five heaviest components of the RNA polymerases from the methanogens (next section) and their cross-reactions with the RNA polymerases from sulfur-dependent archaebacteria, eubacteria and eukaryotes ${ }^{[24]}$.

The purified RNA polymerases of the six methanogens investigated consist each of $7-8$ poly peptides differing in molecular masses (Fig. 2, Table 1). The additional polypeptide (molecular mass $27000 \mathrm{Da}$ ) present in the enzyme of $M b$. thermoautotrophicum, strain Marburg, (Fig. 2) probably represents an impurity, as it did not copurify with the activity peak.

The molecular masses of the native RNA polymerases calculated from the molecular masses and the molar ratios of the constituent enzyme components range from 334000 to $421000 \mathrm{Da}$ (Table 1).

\section{Enzymology}

Enzymatic properties including optimal $\mathrm{MgCl}_{2}$ and $\mathrm{KCl}$ concentrations and $\mathrm{pH}$ and temperature optima determined for the RNA polymerases from six methanogens are listed in Table 2. They all require bivalent cations for activity. At optimal $\mathrm{Mg}^{2 \oplus}$ concentrations (between 10$30 \mathrm{~mm}$ ) the RNA polymerases exhibit an activity which is $3-5$ times higher than that at optimal $\mathrm{Mn}^{2 \oplus}$ concentrations (data not shown). The RNA polymerases of the Methanococcales and Methanomicrobiales show optimal activity at $\mathrm{KCl}$ concentrations lower than those required by enzymes from the Methanobacteriales (Table 2). This decrease in the $\mathrm{KCl}$ requirement for RNA polymerase activity coincides with the lower internal salt concentrations found to be present in Methanococcus and Methanosarcina when compared with Methanobacterium ${ }^{[27]}$.

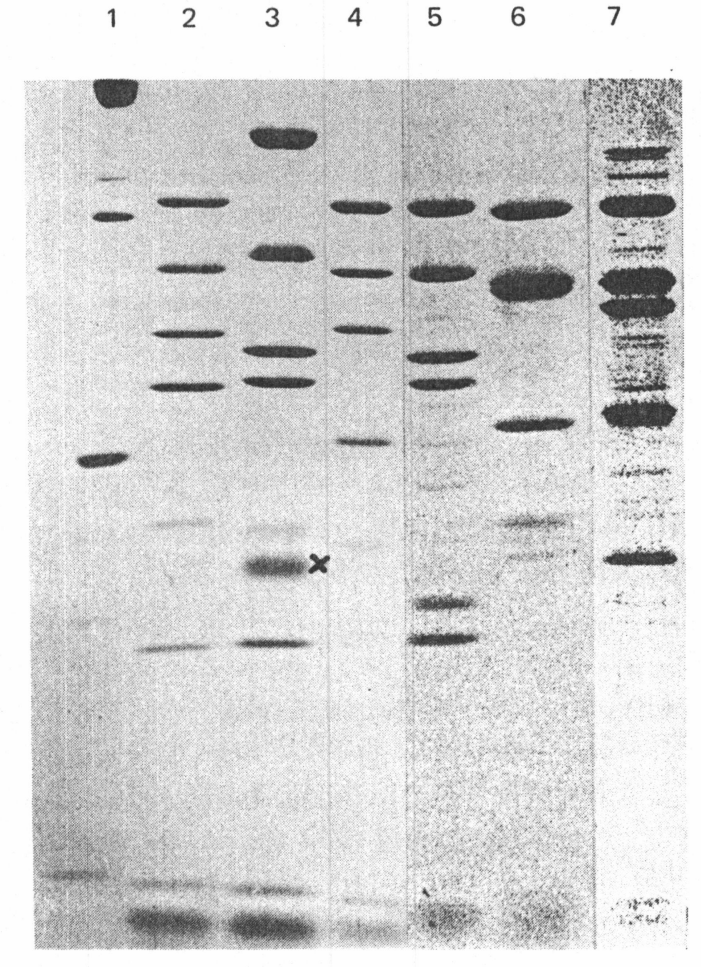

Fig. 2. Dodecyl sulfate polyacrylamide gel electrophoresis of RNA polymerases from representatives of the three orders of methanogens.

RNA polymerases of (2) Mb. thermoautotrophicum, strain W, (3) Mb. thermoautotrophicum, strain Marburg, (4) Mth. fervidus, (5) Mc. thermolithotrophicus, (6) PL12/M, (7) Methanosarcina spec. and (1) E. coli as standard. $\mathrm{x}$ ) Additional polypeptide (molecular mass $=27000 \mathrm{Da}$ ).

\section{Thermostability of the RNA polymerases}

In the cases of PL12/M, Methanosarcina, $M b$. thermoautotrophicum, strains W and Marburg, and $M c$. thermolithotrophicus, the optimal transcription-temperature in vitro correlates very well with the temperature required for optimal growth (Table 2, Fig. 3). The purified 


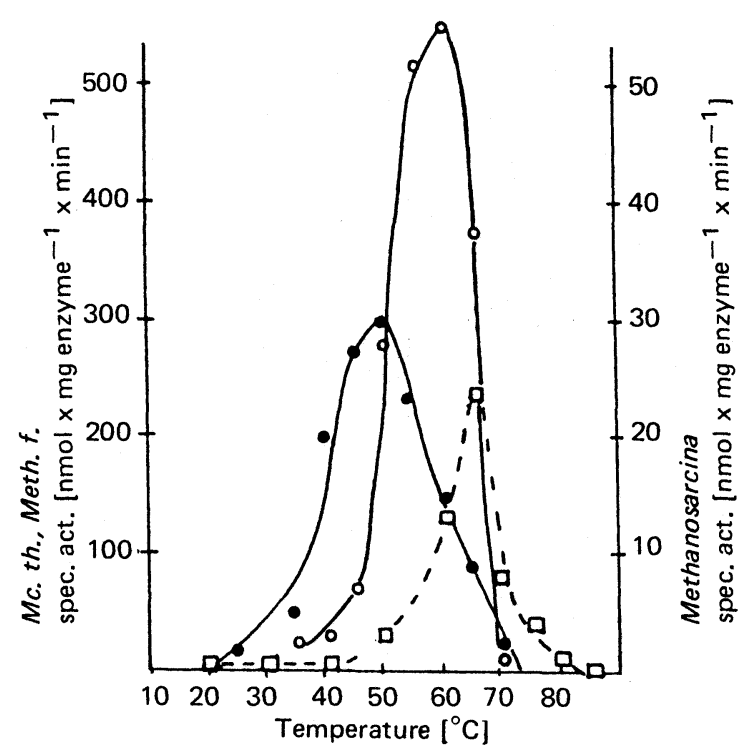

Fig. 3. Temperature dependence of transcription by different RNA polymerases.

Purified RNA polymerases of Mc. thermolithotrophicus $(\bigcirc-0)$, Methanosarcina $(\bullet \longrightarrow)$ and Mth. fervidus $(\square--\square)$ were incubated at different temperatures in standard assays.

enzyme of the extreme thermophile $M t h$. fervidus, however, is inactive at $85^{\circ} \mathrm{C}$ (Fig. 3), a temperature close to that resulting in the optimal growth of this strain ${ }^{[8]}$.

In order to investigate the possible existence of stabilizing factors, the enzyme activity was determined after preincubation of a crude extract for varying times at $80{ }^{\circ} \mathrm{C}$ in the standard assay. About $84 \%$ of the activity were destroyed at $80{ }^{\circ} \mathrm{C}$ within $2 \mathrm{~min}$ (Fig. $4 \mathrm{a}$ ). At $60^{\circ} \mathrm{C}$, however, the enzyme remained stable for $10 \mathrm{~min}$ (Fig. 4a) and the RNA synthesis was linear at least for $10 \mathrm{~min}$ (Fig. 4 b). At $80^{\circ} \mathrm{C}$, however, the enzyme was inactivated after $5 \mathrm{~min}$, as indicated by the plateau (Fig. 4b).

No stabilization of the RNA polymerase could be achieved by the addition of glycerol (up to $50 \%$ ), bovine serum albumine (up to $20 \mathrm{mg} / \mathrm{ml}$ ), calf thymus DNA (up to $5 \mathrm{mg} / \mathrm{ml}$ ), bivalent cations $\left(5-500 \mathrm{mM} \mathrm{MgCl}_{2}\right)$, reducing agents like dithiothreitol $(5-50 \mathrm{mM})$, dithionite $(5-50 \mathrm{mM})$, sodium sulfide $(22 \mathrm{mM})$ and polyamines (putrescine $(1-30 \mathrm{mM})$, spermine $(3 \mathrm{mM})$ and spermidine $(3 \mathrm{mM})$ to the incubation mix ture. In contrast to all other methanogens in extracts of $M t h$. fervidus, no precipitation of proteins could be observed at ammonium sulfate concentrations up to $100 \%$. Therefore, also the effect of saturated salt solutions $\left[\mathrm{KCl},\left(\mathrm{NH}_{4}\right)_{2} \mathrm{SO}_{4}\right]$ was studied. No significant stabilization by salt was detected, however (data not shown).
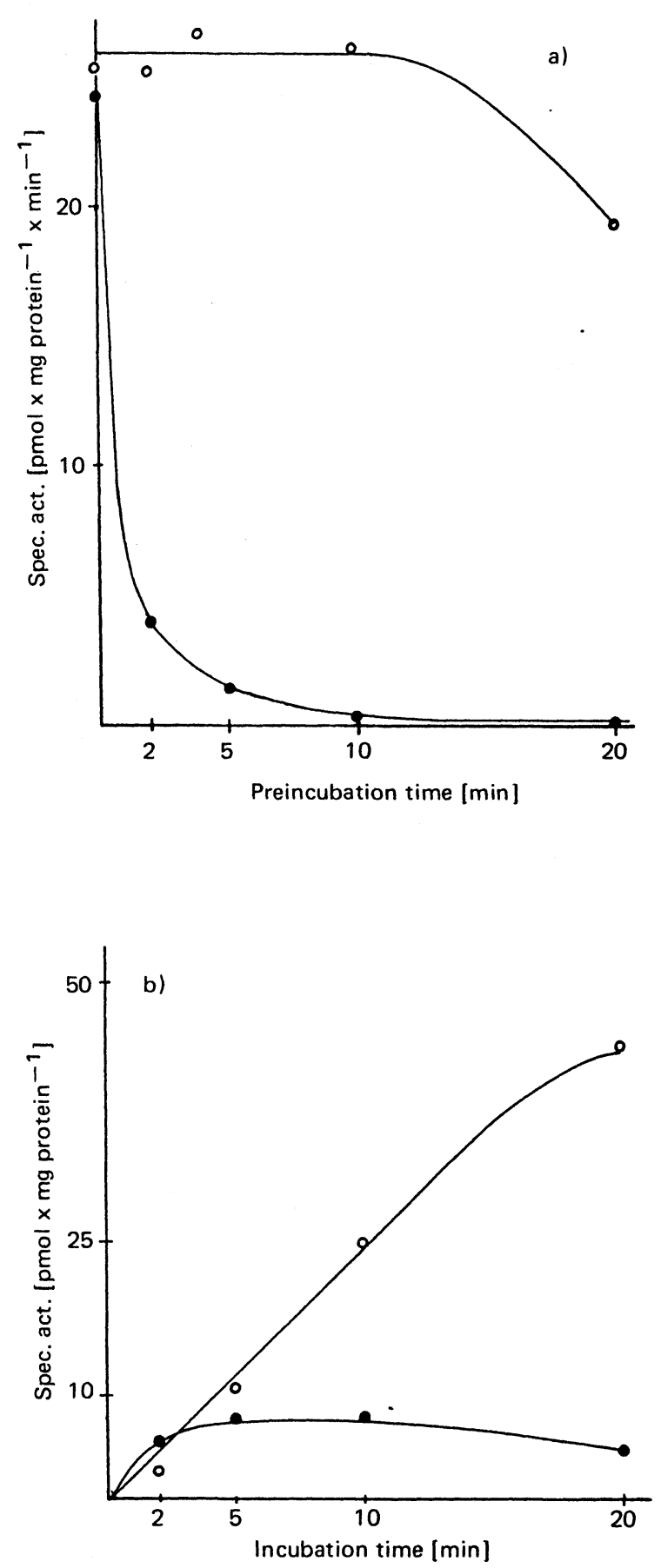

Fig. 4. Effect of temperature on the stability of the RNA polymerase activity in crude extracts of $M t h$. fervidus.

a) $200 \mu l$ crude extract of Mth. fervidus was preincubated for different lengths of time at $80{ }^{\circ} \mathrm{C}$

and $60^{\circ} \mathrm{C}(\mathrm{O}-\mathrm{O})$ and the remaining activity of a $5 \mu l$ aliquot was determined in standard assays containing poly[d(A-T)] as template. As transcription of poly$[\mathrm{d}(\mathrm{A}-\mathrm{T})]$ is not affected by actinomycin $\mathrm{D}$, this antibiotic was added to a final concentration of $100 \mu \mathrm{g} / \mathrm{ml}$ to prevent transcription of the endogenous DNA. b) $10 \mu l$ crude extract were incubated for different lengths of time at $80^{\circ} \mathrm{C}(\longrightarrow)$ and $60^{\circ} \mathrm{C}\left({ }^{\circ} \mathrm{O}\right)$ in standard assays containing actinomycin $\mathrm{D}$. The values in a) and b) were corrected for template-independent radioactivity incorporation $(10-20 \%)$. 
Fig. 5. Immunodiffusion of antisera against the RNA polymerase of Methanosarcina spec. (a), $M c$. thermolithotrophicus (b) and Mb. thermoautotrophicum, W (c) against different RNA polymerases.

$2-10 \mu \mathrm{g}$ of purified RNA polymerases were used. The sequence of RNA polymerases from the top in clockwise direction is

a) Methanosarcina $(10 \mu \mathrm{g}) ; \mathrm{PL} 12 / \mathrm{M}$, Methanosarcina $(2 \mu \mathrm{g}) ;$ Mc. thermolithotrophicus; $M b$. thermoautotrophicum, $\mathrm{W}$;

b) Mc. thermolithotrophicus; Methanosarcina; Mb. thermoautotrophicum, W; PL12/M;

c) Mb. thermoautotrophicum, W, Mb. thermoautotrophicum, Marburg; Mth. fervidus; Mc. thermolithotrophicus; Methanosarcina; PL12/M.

\section{Immunological relations of RNA polymerases}

a) Cross-reaction between native enzymes Antisera against the native RNA polymerase of each representative of the three orders of methanogens (Methanosarcina, Mc. thermolithotrophicus, $M b$. thermoautotrophicum) were raised in order to investigate the immunological relations of the RNA polymerases of methanogens. Using the Ouchterlony immunodiffusion assay, no crossreaction was observed between the enzymes from different orders of methanogens (Fig. 5a-c). Investigation of two representatives from different families of the Methanobacteriales, $M b$. thermoautotrophicum and Methanothermus fervidus, showed (Fig. 5c) that no cross-reaction took place even between different families of one order. The enzyme of Methanosarcina, however, spurred against that of PL12/M (Fig. 5a), thus indicating an immunochemical similarity between these enzymes.

The RNA polymerases of $M b$. thermoautotrophicum, strains W and Marburg, which have been classified as two different species of one genus $^{[7]}$, yielded a confluent line in the Ouchterlony assay (Fig. $5 \mathrm{c}$ ), thus indicating immunochemical identity.

\section{b) Component homology determined by serological cross-reaction}

The antiserum against the heaviest component (A) of the RNA polymerase of $M b$. thermoautotrophicum, $\mathrm{W}$, reacted with the corresponding poly peptide of the RNA polymerase of $M t h$. fervidus (Fig. 6, lanes 2 and 7), and - in spite of the large difference in the molecular mass (Fig. 2; Table 1) - also with the heaviest polypeptide of the enzyme of $M b$. thermoautotrophicum, Marburg (Fig. 6, lanes 2 and 6). Antibodies directed against the second (B'), third $\left(\mathrm{B}^{\prime \prime}\right)$ and fourth $(\mathrm{C})$ components of the enzyme also bound to the corresponding poly- peptides of the two other members of the Methanobacteriales as well as to the enzymes of representatives of the Methanomicrobiales ${ }^{[5,6]}$ and the Methanococcales ${ }^{[7]}$, as shown schematically in Fig. 6. As the single exception the B"component of PL12/M shows a higher apparent molecular mass than $\mathrm{B}^{\prime[6]}$ (Fig. 6, lane 4). The

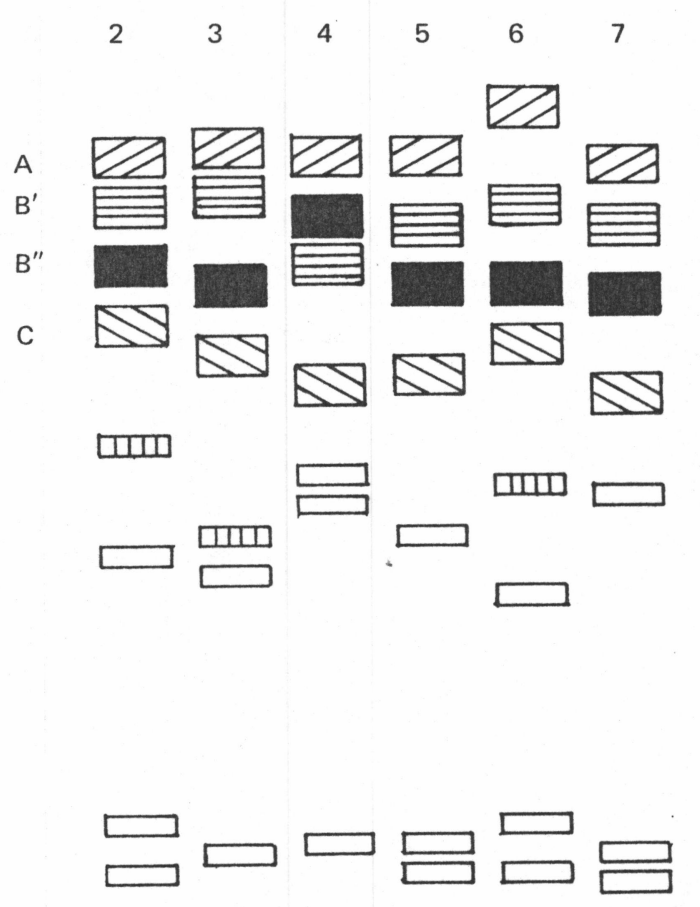

Fig. 6. Homology of the components of DNA-dependent RNA polymerases of methanogens.

The polypeptide patterns of the RNA polymerases shown in Fig. 3 are drawn schematically. Homologous components $(\mathrm{A}-\mathrm{C})$ are characterized by equivalent distinguishing marks. For the detection of immunological cross-reactions, antisera against the single components of the RNA polymerase of $M b$. thermoautotrophicum, W were employed. RNA polymerase of (2) Mb. thermoautotrophicum, W, (3) Mc. thermolithotrophicus, (4) PL12/M, (5) Methanosarcina, (6) Mb. thermoautotrophicum, Marburg (7) Mth. fervidus. 
antibodies against smaller polypeptides of $M b$. thermoautotrophicum, W reacted, with some exceptions (Fig. 6), only with the homologous polypeptides.

\section{Discussion}

The four heaviest components of the DNAdependent RNA polymerases of all methanogens investigated are homologous in spite of their exhibiting different molecular masses. Similar to the case of the enzymes of sulfur-dependent archaebacteria, the RNA polymerases of methanogens consists of 7-8 poly peptides. The enzymes of all methanogens, however, represent a distinct type of RNA polymerase characterized by the occurrence of two polypeptides (designated $B^{\prime}$ and $B^{\prime \prime}$ ), which are serologically related to different parts of the heaviest polypeptide (designated B) of the sulfur-dependent archaebacteria $^{[5,24]}$. The occurrence of unique RNA polymerase subunit structures within the methanogens and the sulfur-dependent archaebacteria is further evidence for the existence of two main branches within the archaebacteria as deduced from 16S rRNA analyses ${ }^{[28-30]}$.

The application of antisera against native RNA polymerases of methanogens proved to be useful for the classification of new isolates: the lack of a cross-reaction of the enzyme of $M t h$. fervidus with antiserum against the RNA polymerase of $M b$. thermoautotrophicum, $\mathrm{W}$ indicated the presence of a considerable phylogenetic gap between these strains. This result coincides with the rather low $S_{A B}$ value of 0.36 found between these organisms (Stackebrandt, Woese, pers. comm.). The absence of cross-reaction of RNA polymerases from different orders in the Ouchterlony-assay (Fig. 5) showed, in addition, that the immunochemical results are consistent with those derived from 16S rRNA oligonucleotide catalogues. Furthermore, the serological identity of the RNA polymerases of $M b$. thermoautotrophicum, strains $\mathrm{W}$ and Marburg, corroborates the close relationship of these strains revealed by DNA/DNA-hybridization studies $^{[7]}$.

The serological cross-reaction of the PL12/M enzyme with the RNA polymerase of Methanosarcina in the Ouchterlony assay yielded evidence that PL12/M is related to the family of the Methanosarcinaceae. This finding is in line with their common ability to grow on methyl compounds. Cataloguing of the $16 \mathrm{~S}$ rRNA of Ms. barkeri and isolate PL12/M revealed a similarity coefficient $\left(\mathrm{S}_{\mathrm{AB}}\right.$-value $)$ of 0.49 (Alten and Stackebrandt, pers. comm.), indicating that both species belong to different genera of the same family, the Methanosarcinaceae.

Taking the classification of methanogens according to Balch et al. ${ }^{[9]}$ into consideration, the following conclusions can be drawn from our immunochemical studies: no cross-reaction with a distinct antiserum signifies that the two organisms compared belong to taxa higher than those comprising genera, e.g. to families or orders. Incomplete cross-reaction (spurring) indicates different genera; immunological identity (confluent precipitation line) indicates that the organisms should be placed within the same genus or species, depending on other criteria.

In contrast to the RNA polymerases of sulfurdependent archaebacteria ${ }^{[13]}$, the enzyme of the extreme thermophile $M t h$. fervidus is not stable in vitro at high temperatures. At $80^{\circ} \mathrm{C}, 3{ }^{\circ} \mathrm{C}$ below the optimal growth temperature of the organism $^{[8]}$, the enzyme is inactivated to an extent of $86 \%$ within 2 min, whereas the enzyme of Sulfolobus acidocaldarius, for example, is completely stable at this temperature ${ }^{[13]}$. The lack of stability of the purified enzyme seems not to be due to the separation of enzyme-stabilizing factors during the purification procedure, as the RNA polymerase in highly concentrated crude extracts was inactivated at the same rate. Transcription at physiological growth temperatures, therefore, appears to depend on the integrity of cell structure.

We thank Petra Frischeisen, Claudia Scheimer and Gerta Lauerer for technical assistance and Christine Stadler for preparing the typescript. This work was supported by grants of the Deutsche Forschungsgemeinschaft (DFG) and the Fonds der Chemischen Industrie.

\section{Literature}

1 Balch, W.E., Fox, G.E., Magrum, L.J., Woese, C. R. \& Wolfe, R.S. (1979) Microbiol. Rev. 43, 260-296.

2 Stetter, K.O. (1984) in Microbial Growth on $C_{1}$ Compounds, Proc. 4th Int. Symp. (Crawford, R. L. \& Hanson, R.S., eds.) pp. 177-181, American Society of Microbiology, Washington, D.C.

3 Stetter, K.O., Winter, J. \& Hartlieb, R. (1980) Zentralbl. Bakt. Hyg., I. Abt. Orig. C1, 201-214.

4 Thomm, M. \& Stetter, K.O. (1985) Eur. J. Biochem. 149, 345-351.

5 Schnabel, R., Thomm, M., Gerardy-Schahn, R., Zillig, W., Stetter, K.O. \& Huet, J. (1983) EMBO J. 2, 751-755.

6 Zillig, W., Schnabel, R., Stetter, K.O., Thomm, M., Gropp, F. \& Reiter, W.D. (1985) in Evolution of Prokaryotes (Schleifer, K.H. \& Stackebrandt, E., eds.) pp. 45-72, Academic Press, London.

7 Brandis, A., Thauer, R.K. \& Stetter, K.O. (1981) Zentralbl. Bakt. Hyg., I. Abt. Orig. C2, 311-317. 
8 Stetter, K.O., Thomm, M., Winter, J., Wildgruber, G., Huber, H., Zillig, W., Janekovic, D., König, H., Palm, P. \& Wunderl, S. (1981) Zentralbl. Bakt. Mikrobiol. Hyg., Abt. I. Orig. C2, 166-178.

9 Balch, W.E. \& Wolfe, R.S. (1976) Appl. Environ. Microbiol. 32, 781-791.

10 Zillig, W., Stetter, K. O., Schnabel, R., Madon, J. \& Gierl, A. (1982) Zentralbl. Bakt. Mikrobiol. Hyg., Abt. I. Orig. C3, 218-227.

11 Humphries, P., McConell, D.J. \& Gordon, R. I. (1973) Biochem. J. 133, 20 1-203.

12 Madon, J. \& Zillig, W. (1983) Eur. J. Biochem. 133, 471-474.

13 Prangishvilli, J., Zillig, W., Gierl, A., Biesert, L. \& Holz, I. (1982) Eur. J. Biochem. 122, 471-477.

14 Stetter, K.O. (1977) Hoppe-Seyler's Z. Physiol. Chem. 358, 1093-1104.

15 Ouchterlony, Ö. (1962) in Progress in Allergy VI (Kallod, P. \& Waksman, B.H., eds.) pp. 30-154, Karger, Basel.

16 Towbin, H., Staehelin, T. \& Gordon, J. (1979) Proc. Natl. Acad. Sci. U.S.A. 76, 4350-4353.

17 Laemmli, U.K. (1970) Nature (London) 227 , 680--685.

18 Mirault, M.E. \& Scherrer, K. (1971) Eur. J. Biochem. 23, 372-386.

19 Heil, A. \& Zillig, W. (1970) FEBS Lett. 11, $165-$ 168.
20 Zillig, W., Zechel, K. \& Halbwachs, H. (1970) Hoppe-Seyler's Z. Physiol. Chem. 351, 221-224.

21 Stetter, K.O. \& Zillig, W. (1974) Eur. J. Biochem. 48, 527-540.

22 Babinet, C. (1976) Biochem. Biophys. Res. Commun. 26, 639-644.

23 Madon, J., Leser, U. \& Zillig, W. (1983) Eur. J. Biochem. 135, 279-283.

24 Gropp, F., Reiter, W.D., Schnabel, R., Zillig, W., Thomm, M. \& Sentenac, A. (1986) System. Appl. Microbiol., in press.

25 Zeikus, J.G. \& Wolfe, R.S. (1972) J. Bacteriol. 109, 707-713.

26 Huber, H., Thomm, M., König, H., Thies, G. \& Stetter, K. O. (1982) Arch. Mikrobiol. 132, 47-50.

27 Matheson, A. \& Yaguchi, M. (1982) Zentralbl. Bakt. Hyg., I. Abt. Orig. C 3, 192-199.

28 Fox, G.F., Stackebrandt, E., Hespell, R.B., Gibson, J., Maniloff, J., Dyer, T.A., Wolfe, R.S., Balch, W.E., Tanner, R.S., Magrum, L.J., Zablen, L. B., Blakemore, R., Gupta, R., Bonen, L., Lewis, B.J., Stahl, D. A., Luehrsen, K. R., Chen, K.N. \& Woese, C. R. (1980) Science 209, 457-463.

29 Tu, J., Prangishvilli, D., Huber, H., Wildgruber, G., Zillig, W. \& Stetter, K.O. (1982) J. Mol. Evol. 18, $109-114$

30 Woese, C. R., Gupta, R., Hahn, C. M., Zillig, W. \& Tu, J. (1984) System. Appl. Microbiol. 5, 97-105.

Dr. Michael Thomm and Prof. Dr. Karl O. Stetter, Lehrstuhl für Mikrobiologie der Universität Regensburg, Universitätsstr. 3 1, D-8400 Regensburg;

Dr. Jerzy Madon, Eidgenössische Technische Hochschule, Mikrobiologisches Institut, Universitätsstr. 2, CH-8006 Zürich. 